\title{
The Adaptation Differences in Terms of Gender on Students in Ulumul Qur'an Stabat Islamic Boarding School
}

\author{
Nini Sri Wahyuni ${ }^{1}$, Nurhayati Barus ${ }^{2}$ \\ ${ }^{1,2}$ Faculty of Psychology, Universitas Medan Area, Medan, Indonesia
}

\begin{abstract}
This research aims to adjustment see the difference self in terms of gender performed by students of boarding schools, where good adaptability are in case there is no excess, no emotional obtained psychological mechanism, a feeling of frustrated personal, ability to learn, the utilization of the experience of the past, realistic and objective stance and rational considerations and direct self. Where the subject of the research is male and female students Class VII MTs ulumul qur'an Stabat that add up to 60 students using simple random sampling technique. Measuring instrument used is liket scale consisting of 64 item and after do try out at 40 students, a valid item becomes 55 item. Based on the data analysis noted that: there is a significant difference in adaptability on student boarding schools in terms of gender, the results of data analysis with the correlation of the T-Test revealed differences with the coefficient of T-Test, $F=1,377$ with $P=0000<0050$. It is declared that the adaptability of male students is higher than female students. Females students having adaptability which are with the empirical mean 145.17 and hypothetic 137.5. Based on the analysis of the data, then the hypothesis presented in this research were declared admissible, namely distinction adaptability according to the gender in which conformity to higher male than female.
\end{abstract}

Keywords

adaptability, students, gender

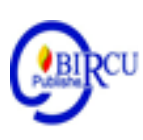

\section{Introduction}

An individual is not born in a condition capable of adjusting or unable to adjust, Harton $\&$ Sunarto (in Safura \& Supriantini, 2006). Many individuals who suffer and feel unable to achieve happiness in their lives, because of their inability to adapt well in family life, school, work, and in society in general, Mu'taadin (in Safura \& Supriantini, 2006). The problem of adjustment in schools can arise when children enter a new school level, such as junior high school, Hartono \& Sunarto (in Safura \& Supriantini, 2006).

At the junior high school (SMP) students are at the stage of adolescent development, precisely the early adolescents namely those aged 12 to 15 years, Monks (in Safura \& Supriantini, 2006). At this time difficult developmental tasks for students are those related to social adjustment, Hurlock (in Safura \& Supriantini, 2006). In this social adjustment also requires the ability of individuals to follow these changes or also called personal adjustment, Mappiare (in Safura \& Supriantini, 2006).

In Bernard (in Safura \& Supriantini, 2006), there are three problems related to adaptation in schools, namely with peer groups, conformity with teachers, and adjustment with parents, teachers and students.

According to Hawkins \& Berndt, (in Santrock, 2002) the transition from elementary to junior highschool is also called the top-dog phenomenon, where there is a movement from an upper position (in elementary school, they are the oldest, largest, and most students the most powerful in school) to the lowest position (in high school or junior high school, being the 
youngest, smallest, and weakest students in school). This often creates problems for many students who are unable to adjust to new situations.

\section{Review of Literature}

\subsection{The Definition of Students}

According to the Indonesian Dictionary (KBBI), students are students at the academy. According to a pedagogical perspective, students are a type of creature that grants education, in the sense that students are called 'homo educandum' creatures. Students or students are the core components in educational activities, students or students as the main problem in educational interactions.

According to Hamalik (2010) students are unique individuals who have physical, psychological, and intellectual readiness and abilities that are different from each other, as well as only in the process of activating behavior and learning processes, are following or adjusting to all activities and demands made by the teacher.

According to Khan (in Patrecia, 2013) understanding students are students who come to an institution to acquire or learn science at any age, from anywhere, anyone, in any form, at any cost to improve their intellect and morals in order to develop and cleanse their souls and following the path of kindness.

Djamarah (2011) which states that students are unique individuals and have the potential to develop. Meanwhile, according to Daradjat (in Patrecia, 2013) students are "unique" individuals who have the potential and experience a developing process. In the process of developing that students need help whose character and style are not determined by the teacher but by the student himself, in a life together with other individuals.

\subsection{The Definition of Boarding Schools}

The boarding schools, according to Prof. Johon (in Zega, 2010), came from Tahlil language, santri which means the teacher of Al-Quran. Berg also believes that the term santri comes from the word Shastri (Indian language) which means students who know the Hindu religious books or scholars of the Hindu religious scripture. The word shastri comes from the word shastra which means holy books, religious books or books about science.

Ngitjo (2008) mentions Islamic boarding school is an alternative educational institution for school-age children who are Muslim, where this institution combines school education with religion. The purpose of this educational institution is to prepare young students who can master science while mastering religious knowledge to strengthen morals (behavior). Most of the time the students are used to study Islamic religious knowledge, without leaving science learning activities in general such as in public schools. Usually the boarding school neighborhoods are called Madrasas.

Islamic boarding schools offer a different curriculum compared to public schools. Some Islamic boarding schools integrate government curriculum with curriculum made by boarding schools, so that apart from being equipped with general knowledge, students can also deepen religious knowledge. The students who study at Islamic boarding schools are expected to be able to master the knowledge of also having priests and piety who as provisions for community life. The santri live in a unique community, with the kyai, religious teacher, and santri and boarding school administrators, based on Islamic religious scorescomplete with their own norms and habits, which are not infrequently different from the general public that surrounds them. Bashori (in Pritanigrum and Hendriani, 2013). 


\subsection{The Definition of Self-Adjustment}

The notion of adaptation was originally derived from the understanding which is based on the science of biology, which was pointed out by Charles Darwin who was famous for the theory of evolution. He said "genetic changes can improve the ability of organisms to survive, reproduce, and, in animals, raise offspring, this process is called adaptation". This means that human behavior can be viewed as a reaction to the various demands and pressures of the environment in which it lives, such as the weather and various other natural elements. All living things are naturally equipped with the ability to help themselves by adapting to the natural environment to survive (in Fatimah, 2010).

In psychology, self-adjustment (adaptation in biological terms) is called adjustment. Adjustment is a process to reach a meeting point between self-conditions and environmental demands. Davidoff (in Fatimah, 2010). Humans are required to adapt to the social, psychological and natural environment. Life naturally also encourages humans to constantly adjust.

According to Schneiders (in Pritaningrum and Herdiani, 2013) self-mortification is a process that includes mental response and behavior, in this case the individual will try to overcome the tension, frustration, needs, and conflicts that originate from within him well and produce a degree of conformity between demands which comes from within himself with the objective world in which individuals live. The ability of each individual is not always the same. Some are able to adjust but there are also individuals who are not able to adjust.

Adjustment according to Suwarno (in Ingrid, 2008) is one of the creation of individual mental or mental health. Many individuals suffer and are unable to achieve happiness in their lives, due to their inability to adapt, both to family life, school, work and society in general. Not infrequently the assumption of a person's life experiencing stress and depression caused by their failure to make adjustments to the life that has ever been experienced.

\section{Research Method}

This type of research is quantitative, which is a study that emphasizes its analysis of numerical data (numbers) processed by statistical methods. With quantitative methods significant group differences or significant relationship variables will be obtained. (Arikunto, 2005).

Variables are all things that can change the variables in this study are as follows:

1. Independent variable: Gender (X)

2. Dependent variable: self-adjustment (Y)

The operational definition is a definition of variables that are formulated based on the characteristics of these variables that can be observed (Azwar, 2007). In this study the operational definitions of variables are made based on the method and measuring instrument chosen, as well as the theoretical framework used. The operational definitions in this study are as follows:

In a population, the sample used is one important factor that must be considered. According to Hadi (2004) the population is a number or individuals who have at least one of the same nature. The population used in this study were all students of class VII MTs Islamic Boarding School Ullumul Qur'an Stabat, amounting to 126 students.

\begin{tabular}{|c|l|l|}
\hline Male & Female & Number of students in class VII \\
\hline 63 & 63 & 126 \\
\hline
\end{tabular}


Considering the relatively large number of population, this research is strived to use a portion of the population called the sample. This is in accordance with the opinion of Arikunto (2006) which states, if the population is relatively large, then the number of subjects can be taken around $10-15 \%$ and $20-25 \%$ or more. Researchers took a sample of $45 \%$ of the population of 60 students.

The sampling technique in this study was done by simple random sampling that is said to be simple (simple) because the sampling of members of the population of the data is carried out randomly without regard to strata in the population. Of the 5 classrooms taken 60 students. Each class is taken by 12 students, 6 males and 6 females. The way to take the lottery numbers is that each student is numbered based on class attendance then the number is randomized in the lottery box. Each student gets the same opportunity to be chosen in the research subject.

\begin{tabular}{|l|l|l|}
\hline Male & Female & Total \\
\hline 30 & 30 & 60 \\
\hline
\end{tabular}

This study uses a method to collect data is the scale method. The scale is a collection of statements submitted in writing to someone (in this case the respondent) and how to answer in a written manner.

According to Hadi (2004) there are several assumptions held by what research when using this method, namely:

1. The subject is the person who knows best about himself.

2. What the research subject says is true and can be trusted.

3. The interpretation of the subject challenges the statements proposed are the same as what is meant by the researcher.

The data collection method used in this study is the Likert scale method, which is a scale that measures adjustment according to gender in Ulumul qur'an Stabat Islamic boarding school students. The scale of self-adjustment ability is arranged based on aspects according to Schneiders (1964) namely there is no emotional overload, no psychological mechanism, no personal frustration, the ability to learn, the use of past experiences, realistic and objective attitudes, and rational considerations and direct yourself. The adjustment scale is based on the Likert scale 4 categories of answers, namely strongly agree (SS), agree (S), disagree (TS), and strongly disagree (STS).

The research item is favorable (support) moving from the score of four for the SS answer, the score of three for the $\mathrm{S}$ answer, the score of two for the TS answer and the score of one for the STS answer. The Unfavorable (not supported) item evaluation moves from score one for SS answers, score two for S answers, score three for TS answers, and four scores for STS answers. The form of the four answers used in the preparation of this scale is due to avoid the possibility of answers in the middle.

Validity is tested by using Product Moment correlation from Karl Pearson with the following formula:

$$
r x y=\frac{\sum X Y-\frac{\left(\sum X\right)\left(\sum Y\right)}{N}}{\sqrt{\left\{\left(\sum X^{2}\right)-\frac{\left(\sum X\right)^{2}}{N}\right\}\left\{\left(\sum Y^{2}\right)-\frac{\left(\sum Y\right)^{2}}{N}\right\}}}
$$

Information:

r.xy $=$ The correlation coefficient between items and the total score 


$\begin{array}{ll}\sum X Y & =\text { Number of multiplications between items and the total score } \\ \sum X & =\text { Number of item scores } \\ \sum Y & =\text { Number of Total score } \\ \sum X^{2} & =\text { Number of squares score } \mathrm{X} \\ \sum_{\mathrm{N}} \mathrm{Y}^{2} & =\text { Number of squares score } \mathrm{Y} \\ \mathrm{N} & =\text { Number of subjects }\end{array}$

Reliability of measuring instruments is to find and know the extent to which the measurement results can be trusted. Reliability can also be said to be trust, care, stability, stability, consistency, and so on. The measurement results can be trusted if in several times the implementation of measurements on the same group of subjects obtained relatively the same results as long as the subjects measured have not changed (Azwar, 1997). The scale to be estimated is the same amount of reliability. To find out the reliability of measuring instruments, the Alpha formula is used as follows:

$$
\alpha=2\left[\frac{1-S 1^{2}=S 2^{2}}{S x^{2}}\right]
$$

\section{Information:}

$\alpha \quad=$ alpha coefficient

$\mathrm{S}^{2}$ and $\mathrm{S}^{2}=$ Hemisphere score 1 variance and Hemisphere score 2 variance

$\mathrm{Sx}^{2} \quad=$ Variance score scale

The analysis used in this study is statistical data with independent sample T-Test that is to find out the differences in the adjustment of boarding schools students in terms of gender in students (class VII).

$$
t-\text { test }=\frac{\mathrm{x}_{1}-\mathrm{x}_{2}}{\sqrt{\left[\frac{\mathrm{SD}_{1}^{2}}{\mathrm{~N}_{1}-1}\right]+\left[\frac{\mathrm{SD}_{2}^{2}}{\mathrm{~N}_{2}-1}\right]}}
$$

Information:

$\mathrm{X}_{1}=$ mean in sample 1 distribution

$\mathrm{X}_{2}=$ mean in the distribution of sample 2

$S D_{1}^{2}=$ Score of variance in the distribution of sample 2

$S D_{2}^{2}=$ Score of variance in the distribution of sample 2

$\mathrm{N}_{1}=$ number of individuals in sample 1

$\mathrm{N}_{2}=$ number of individuals in the sample

\section{Result and Discussion}

This research was conducted on male and female students who attend the Islamic boarding school in Ulumul Qur'an Stabat. The address is K.H.Wahid Hasyim. No.3 Kwala Bingai, Stabat. This boarding schools consists of Madrasah Alliyah (MA) level and Madrasah Tassanawiyah (MTs) levels. With Madrasah Tsanawiyah led by Mr. Rusman.S.Ag. The total number of class VII students who are in MTs ulumul Qur'an Stabat is 126 students.

At the time of the research the subject of this research were students of class VII MTs ulumul Qur'an Stabat consisting of 26 students VII-1, 27 students VII-2, 25 students VII-3, 22 students VII-4 and 26 students VII- 5. And obtained 50 students who qualify as subjects in 
this study. The number of male students was 63 students and female students were 63 students.

Ulumul Qur'an Islamic boarding school Stabat Langkat regency of North Sumatra was established in line with the opening of the Musabaqoh Tilawatil Qur'an at the provincial level of Sumatra in 1986 which was held on earth with Malay Stabat Langkat in North Sumatra. Ulumul Qur'an Islamic Boarding School Stabat Langkat Regency was inaugurated on 2 sya'ban $1406 \mathrm{H}$ or 12 April 1986. This boarding school has formal educational institutions including Madrasah Tsanawiyah (MTs) and Madrasah Aliyah (MA). The vision of the Stabat ulumul qur'an boarding school is the realization of a generation of qur'ani who are pious, knowledgeable, skilled, independent and moral. And the indicators of the Ulumul quran Islamic boarding school are as follows, namely: 1) Realizing the ulumul quran Islamic boarding school as a center for Islamic education. 2) Creating a cadre of moral and moral leaders according to the demands of the Qur'an. 3) Creating a cadre of scholars, Huffazh and qurra 'al-quran'. 4) Creating a cadre of fahmil quran, khaththil quran and mufassir quran. 5) Improve the quality of skilled, innovative and independent resources. 6)

Before this research is carried out, preparations related to administrative preparation are held first, namely the application for permission to collect data in the hope that the research process can be carried out smoothly. Before giving a permit, researchers first made a letter requesting data retrieval submitted to the Faculty of Psychology, University of Medan Area with the title "Differences in Adaptation in Terms of Gender in Ulumul Qur'an Stabat students". After the withdrawal of the application was approved, the Faculty issued a letter covering data collection with number: 603 / FPSI / 01.10 / IV / 2017. Then the researchers gave a letter of introduction to the data collection at the Ulumul Qur'an Islamic Boarding School office on the street of K.H.Wahid hasyim No.3 Kwala Bingai, Stabat. After administrative preparations are completed the study is allowed by the boarding schools to conduct research.

Preparation of measuring instruments for research in intended is a tool that will be used to obtain data in this study. The measuring instrument used is to use a scale to reveal the dependent variable and the independent variable. The type of scale used with this research is the scale of adjustment. Before the study, researchers prepared a measuring instrument with aspects of adjustment, to find out whether there are differences in adjustment of male and female students in Islamic boarding schools.

The measurement of adjustment used in this study was prepared based on the aspects of self-adjustment proposed by Schneiders (1964), namely the absence of excessive emotional, no psychological mechanisms, no personal frustration, the ability to learn, the use of past experiences, realistic and objective attitude and rational and self-directed consideration.

The scale used is scale llikert. The scale score of each statement is obtained from the subject statement which states support (favorable) or not support (unfavorable) of each statement in the answer category, namely strongly agree, agree, disagree (TS), strongly disagree. The rating of the moving item is favorable from the number 4 answers strongly agree, 3 to agree, 2 to disagree and 1 to strongly disagree. Rating unfavorable items move from the number 1 answer strongly agree, 2 to agree, 3 to disagree and 4 to strongly disagree. The table below is a scale distribution of self-concept before research.

Table 1. Distribution of Grains of Adjustment Scale (Before Trial Measurement)

\begin{tabular}{|c|c|c|c|c|}
\hline \multirow{2}{*}{ No. } & \multirow{2}{*}{ Aspects of Adjustment } & \multicolumn{2}{|c|}{ Item Number } & \multirow[t]{2}{*}{ Total } \\
\hline & & Favorable & Unfavorable & \\
\hline
\end{tabular}




\begin{tabular}{|c|c|c|c|c|}
\hline 1. & There is no emotional overload & $9,49,48,47$ & $24,6,7,8$ & 8 \\
\hline 2. & $\begin{array}{l}\text { There is no psychological } \\
\text { mechanism }\end{array}$ & $10,46,26,27$ & $23,25,44,47$ & 8 \\
\hline 3. & $\begin{array}{l}\text { There is no personal } \\
\text { frustration }\end{array}$ & $28,22,50,14$ & $58,11,13,12$ & 8 \\
\hline 4. & Ability to study & $42,15,16,43,1,5,2,51$ & $41,59,29,60,38,39,40$ & 16 \\
\hline 5. & Utilization of past experience & $52,55,56,3$ & $54,53,37,19$ & 8 \\
\hline 6. & Realistic and objective attitude & $20,21,57,61$ & $17,30,18,32$ & 8 \\
\hline 7. & Rational considerations & $34,33,62,63$ & $31,64,35,36$ & 8 \\
\hline Total & & 32 & 32 & 64 \\
\hline
\end{tabular}

Based on the trial, it is known that the scale of adjustment of 64 items contained 9 items that have a Corrected item-total correlation score $\left(\mathrm{r}_{\mathrm{xy}}\right.$ difference power index $)<0.3$; namely item number $8,18,26,45,46,52,55,60$. And 55 other valid items have a corrected itemtotal correlation score (differential power index $r_{x y}$ ) $>0.3$; with a moving score from rbt $=$ 0.320 to rbt $=0.635$, with a Cronbach Alpha reliability score of 0.935 . Thus the scale compiled in this study is declared reliable, that is, it can be used at other times in expressing adjustment. The following table is the distribution of the distribution of points of adjustment scale statement after testing.

Table 2. Distribution of statement items scale of adjustment after trial

\begin{tabular}{|c|c|c|c|c|c|c|}
\hline \multirow[t]{3}{*}{ No } & \multirow[t]{3}{*}{ Aspects } & \multicolumn{4}{|c|}{ Item Number } & \multirow[t]{3}{*}{ Total } \\
\hline & & \multicolumn{2}{|c|}{ Favorable } & \multicolumn{2}{|c|}{ Un Favorable } & \\
\hline & & Valid & Eliminated & Valid & Eliminated & \\
\hline 1. & $\begin{array}{l}\text { There is no emotional } \\
\text { overload }\end{array}$ & $9,48,47$ & 49 & $24,6,7$ & 8 & 8 \\
\hline 2. & $\begin{array}{l}\text { There is no psychological } \\
\text { mechanism }\end{array}$ & 10,27 & 46,26 & $\begin{array}{c}23,25 \\
44,47\end{array}$ & & 8 \\
\hline 3. & $\begin{array}{l}\text { There is no personal } \\
\text { frustration }\end{array}$ & $28,22,50,14$ & & $\begin{array}{c}58,11,13 \\
12\end{array}$ & & 8 \\
\hline 4. & Ability to learn & $\begin{array}{c}42,15,16 \\
43,15,2,51\end{array}$ & & $\begin{array}{c}41,59,29 \\
38,39,4,40\end{array}$ & 60 & 16 \\
\hline 5. & $\begin{array}{l}\text { Utilization of past } \\
\text { experience }\end{array}$ & 56,3 & 52,55 & $\begin{array}{l}54,53,37 \\
19\end{array}$ & & 8 \\
\hline 6. & $\begin{array}{l}\text { realistic and objective } \\
\text { attitude }\end{array}$ & $20,21,57,61$ & & $17,30,32$ & 18 & 8 \\
\hline 7. & $\begin{array}{l}\text { Rational and self-directed } \\
\text { consideration }\end{array}$ & $\begin{array}{l}34,33,62 \\
63\end{array}$ & & $\begin{array}{c}31,64,35 \\
36\end{array}$ & 45 & 8 \\
\hline & Total & 27 & 5 & 28 & 4 & 64 \\
\hline
\end{tabular}

Based on testing of measuring devices It is known that the scale of 64 items It is estimated that 9 items are claimed to have an Item-Total Correction score $\left(\mathrm{r}_{\mathrm{xy}}\right.$ difference power index) $<0.3$; that is, items number $8,18,26,45,46,49,52,55,60$. And 55 other valid items have a Item-Total Correction Correction score ( $\mathrm{r}_{\mathrm{xy}}$ different power index) $>0.3$; with a moving score from rbt $=0.320$ to $\mathrm{rbt}=0.635$, with a Cronbach Alpha reliability score (0.935).

As the purpose of the test for the normality of this distribution is to prove the distribution of research data that became the center of attention after being published based on the normal curve principal. The distribution normality test was analyzed by using the 
research data normality test using the Kolmogorov-Smirnov Goodness of Fit Test. Based on this analysis, it is announced as follows followed by the normal distribution that is distributed according to the normal curve principle. As a criterion for translating oneself using a specified scale $p>0.05$ the distribution is declared normal, otherwise it is agreed to agree $p$ $<0.05$ the distribution is declared abnormal.

Table 3. Summary of Calculation Results of the Distribution Normality Test

\begin{tabular}{|l|c|c|c|c|c|}
\hline Variable & RERATA & SB/SD & K-S & P & Information \\
\hline Adjustment & 157.45 & 15.935 & 1.011 & 0.259 & Normal \\
\hline
\end{tabular}

Information:

AVERAGE $=$ Average score

$\mathrm{K}-\mathrm{S} \quad=$ Kolmogorov-Smirnov coefficient

SB $\quad=$ Standard Deviation (Standard Deviation)

$\mathrm{P} \quad=$ significance

Homogeneity variance test is intended to determine whether the research subject is homogeneous. Based on the variance homogeneity test it is known that the research subjects come from homogeneous samples. As a criterion if the score is significant or $p>0.050$, then it is declared homogeneous and if the score is significant or $\mathrm{p}<0.050$, then it is declared not homogeneous. The following is a summary table of the results of the test for variance homogeneity.

Table 4. Summary of Calculation Results for Variance Homogeneity Test

\begin{tabular}{|l|c|c|c|c|}
\hline Variable & Homogeneity Test & F & Sig & Information \\
\hline Adjustment & 157.45 & 15.935 & 1.011 & Normal \\
\hline
\end{tabular}

Based on the results of calculations from the t-test analysis, it is known that there are significant differences in adjustment between male and female. This result is known by looking at the score or coefficient of difference has a significance of 0,000 . This means that the significance score obtained is less than 0.050. Thus the hypothesis that there is a difference in adjustment between male and female, is accepted. The results of the t-test analysis calculations can be seen in the following table.

Table 5. Summary of T-test Analysis Results

\begin{tabular}{|l|l|c|c|c|}
\hline Source & JK & Db & T & Sig \\
\hline Between A & 55.117 & 58 & 9.411 & 0.000 \\
\hline
\end{tabular}

Information:

Between A : Between Adjustments

JK : Number of Squares

$\mathrm{Db} \quad$ : Degrees of Freedom

T : Difference coefficient

Sig : Significance

For the adjustment variable of adolescent males and females, the number of valid items is 55 items formatted with a Likert scale in 4 answer choices, then the hypothetical mean is $\{(55 \times 1)+(55 \times 4)\}: 2=137.5$. 
Based on data analysis, as seen from the t-test analysis it is known that, the adjustment of the male empirical mean is 169.73 and the female adjustment of the empirical mean is 145.17.

In an effort to find out the conditions of adjustment, it is necessary to compare the mean / empirical average score with the mean / hypothetical mean score by taking into account the magnitude of the SD numbers of each. The adjustment of SD males is 11,206 , the adjustment of elementary school females is 8,879 .

From the magnitude of the SD numbers, then if the mean / hypothetical mean score $<$ the mean / empirical average score, where the difference exceeds the SD score, then the adjustment is declared high. If the mean / hypothetical mean score <mean / empirical mean score, where the difference does not exceed the SD score, then the adjustment is stated as low and if the hypothetical mean / mean score is empirical mean / mean, where the difference is not exceeding the SD score, the adjustment is stated to be low. If the mean / hypothetical mean score with the mean / empirical average score has a difference or balance with the SD score, then the adjustment is stated to be moderate. A full picture of the comparison of mean / hypothetical mean scores with empirical mean / mean scores can be seen in the table below.

Table 6. Hypothetical and Empirical Average Score Calculation Results

\begin{tabular}{|l|c|c|c|l|}
\hline \multirow{2}{*}{ Variable } & \multirow{2}{*}{ SB/SD } & \multicolumn{2}{|c|}{ Average score } & \multirow{2}{*}{ Information } \\
\cline { 3 - 4 } & & Hypothetic & Empiric & \\
\hline Male Adjustment & 11.206 & 137.5 & 169.73 & High \\
\hline Female Adjustment & 8.879 & 137.5 & 145.17 & Medium \\
\hline
\end{tabular}

Based on the analysis of the T-test results obtained that there is a significant difference between adjustment to gender in students of Ulumul Qur'an Stabat boarding school with a score of $\mathrm{T}=9,411$; sig $=0,000$. This means that there are differences in adjustment between male and female, otherwise accepted.

From the description of the research results obtained above, it can be seen that the adjustment of students in the ulumul qur'an Islamic boarding school between male and female students has a difference in their self-adjustment, where in adjustment adjusted boarding school male students are better in terms of adjustment compared to female students.

The results of research conducted on boarding students in terms of the theory put forward by Schneider (1964) aspects of adjustment are there is no excessive emotional, no psychological mechanism, there is no personal frustration, the ability to learn, the use of past experience then, realistic and objective attitudes and rational and self-directed considerations. This is also in line with Hidayat's research (in a psychological journal, 2012) in the results of his analysis that the ability of male students to adapt is higher than female students.

The results obtained from this study, it is known that the subject of this study, namely male and female students in the Islamic boarding school Ulumul Qur'an Stabat that male students self-adjustment belongs to the high category, because the empirical scores amounted to 169.73 greater than the hypothetical mean score of 137.5 . While female students in the adjustment are classified in the low category, because the empirical score of 145.17 from the hypothetical average score of 137.5. And it can be concluded that male students tend to be better in self-adjustment than female students.

Based on the description above, students' self-adjustment in Islamic boarding schools, male students better self-adjustment compared to self-adjustment of female students. 


\section{Conclusion}

There is a significant difference in adjustment between male and female in the Islamic Boarding School of Ulumul Qur'an Stabat Islamic Boarding School, where T score $=9,411$; sig $=0,000$ which turns out to prove that there are significant differences in adjustment between male and female. Thus, the hypothesis that there is a difference in adjustment between male and female, is accepted.

In this case it is stated that Islamic boarding school of male students have a high adjustment with an empirical mean of 169.73 and a hypothetical mean of 137.5. Islamic boarding school of female students have low adjustment with an empirical mean of 145.17 with a hypothetical mean of 137.5

\section{References}

Agustiani, H. (2006). Psikologi Perkembangan. Bandung: Refika Aditama.

Ali, M and Asrori, M. (2006). Psikologi remaja, perkembangan peserta didik. Jakarta : PT Bumi Aksara.

Arikunto, S.(2005). Manajemale Penelitian. Jakarta : Rineka Cipta.

Azwar, S. (1992). Reliabilitas dan validitas. Yogyakarta: Pustaka Pelajar.

Azwar, S. (2000). Reliabilitas dan Validitas. Yogyakarta : Sigma Alpha.

Bashori, Khoirudin. (2003). Problem Psikologis Kaum Santri: Resiko Insekuritas Kelekatan. Yogyakarta: Forum Kajian Budaya Dan Agama

Desmita. (2009). Psikologi Perkembangan Peserta Didik (Panduan Bagi Orangtua dan Guru dalam memahami psikologi anak usia SD, SMP, SMA). Bandung: Refika Aditama.

Djahmarah, B.S.(2011). Psikologi Belajar. Jakarta: Rineka Cipta.

Djiwandono, S.E.W.,(2002). Psikologi pendidikan. Jakarta: Gramedia Widiasarana Indonesia.

Fahmi, M. (1982). Penyesuaian Diri. Jakarta: Bulan Bintang.

Fatimah, E. (2006). Psikologi perkembangan, perkembangan peserta didik. Bandung: CV Pustaka Setia.

Hadi, S. (2004). Statistik jilid 2. Yogyakarta: Andi offset.

Hamalik, O.(2010). Proses Belajar Mengajar. Jakarta: Bumi Aksara.

Hawan. (1997). Penyesuaian diri pada remaja. Jakarta : Erlangga.

Hidayat, D.A. (2012). Perbedaan penyesuaian diri santri pondok boarding schools Tradisional dan moderen. Talenta Psikologi,vol.1 No.2, Agustus 2012.

Hurlock, E.B. (1980). Psikologi Perkembangan.Suatu Pendekatan SepanjanRentan Kehidupan. Jakarta: Erlangga.

Hurlock, E. B.(1997). Perkembangan anak. Jakarta: Erlangga.

Hurlock, E.B. (2003). Psikologi Perkembangan. Suatu Pendekatan Sepanjang Rentang Kehidupan. Jakarta: Erlangga.

Ingrid, S. 2008. Hubungan penyesuaian diri dengan lingkungan sekolah di SMA Negeri 1 Pematang Siantar. Skripsi (tidak diterbitkan). Medan Fakultas Psikologi Universitas Medan Area.

Sihombing, J. P. 2015.Hubungan Self efficacy dengan Penyesuaiana Diri Siswa Asrama SMA Swasta Katolik Sibolga. Skripsi (tidak diterbitkan). Medan : Fakultas Psikolog Universitas Medan Area. 
Kartono, K. (2002). Psikologi Perkembangan. Jakarta: Rineka Cipta.

King, Laura.A. 2013. Psikologi Umum : Sebuah pandangan apresiatif. Jakarta: Salemba humanika.

Kusdiyati, Sulisworo \& Halimah, Faisaluddin. 2011. Penyesuaian Diri diLingkungan Sekolah Pada Siswa Kelas XI SMA Pasundan 2 Bandung. Jurnal Psikologi,vol. VIII No.2. Universitas Islam Bandung.

Mahmudin and Suroso.(2004). Efikasi Diri, Dukungan Sosial, Dan Penyesuaia dalam belajar. Pesona Jurnal Psikologi Indonesia, Vol.3,No.02, hal 183-194, Mei 2014.

Mentari, A.T. 2015. Perbedaaan Coping Stress Pada Individu Yang Berkerja Ditinjau Dari Jenis Kelamin. Skripsi (tidak diterbitkan). Medan :Fakultas Psikologi Universitas Medan Area.

Pritaningrum, M and Hendriani, W. (2013). Penyesuaian Diri Remaja Yang Tinggal Di Pondok Boarding schools Modern Nurrul Izzah Gersik Pada Tahun Pertama. Jurnal Psikologi Kepribadian Dan Sosial, Vol.02,No.03, Desember 2013.

Safura, L and Supriantini, S. (2006). Hubungan antara penyesuaian diri anak disekolah dengan prestasi belajar. Psikologia, volume 2,No.1,Juni 2006.

Santrock, J.W. (2008). Psikologi Pendidikan (edisi kedua). Jakarta : Kencana.

Santrock, J.W. (2009). Psikologi pendidikan (Terjemahan). Jakarta : Salemba.

Santrock, J.W.(2007). Remaja: Edisi II jilid 2 (terjemahan). Jakarta: Erlangga.

Sugiono. (2015). Metode penelitian pendidikan pendekatan kuantitatif, kualitatif dan $R \& D$. Bandung. Alfabeta.

Sugiono. (2014). Metode Penelitian Pendidikan Pendekatan Kuamtitatif, ------- Kuantitatif dan R\&D. Bandung.Alfabeta.

Sukmadinata, N. (2008). Metode Penelitian Pendidikan. Bandung: PT.Remaja Rosdakarya.

Yusrika. 2012. Perbedaan Penyesuian Diri Ditinjau Dari Jenis Kelamin Pada Pada Mahasiswa Indekost Stambuk 2011 Di Fakultas Psikologi Universitas Medan Area. Skripsi ( tidak diterbitkan). Medan : Fakultas Psikologi Universitas Medan Area.

Zega, Z. 2014. Perbedaan Moralitas antara Siswa Boarding schools dan Non Boarding schools. Skripsi (tidak diterbitkan). Medan: Fakultas Psikologi Medan Area. 